\title{
ASSESSMENT OF THE RESULTS OF ACCESSORY TO SUPRASCAPULAR NERVE TRANSFER
}

\section{AVALIAÇÃO DOS RESULTADOS DA TRANSFERÊNCIA DO NERVO ACESSÓRIO PARA O SUPRAESCAPULAR}

\author{
Yussef Ali Abdouni ${ }^{1}$, Gabriel Faria Checoli ${ }^{1}$, Horacio Cardoso Salles Filho ${ }^{1}$, Antonio Carlos da Costa ${ }^{1}$, Ivan Chakkour $^{1}$, \\ Patricia Maria de Moraes Barros Fucs ${ }^{1}$
}

1. Irmandade da Santa Casa de Misericórdia de São Paulo, Departament of Orthopaedics and Traumatology, São Paulo, SP, Brazil.

\begin{abstract}
Objective: Nerve transfers are an alternative in the reconstruction of traumatic brachial plexus injuries. In this study, we report the results of branchial plexus reconstruction using accessory to suprascapular nerve transfer. Methods: Thirty-three patients with traumatic brachial plexus injuries underwent surgical reconstruction with accessory to suprascapular nerve transfers. The patients were divided into groups in which surgery was performed either within 6 months after the injury or more than 6 months after the injury. Results were assessed using the Constant score. Results: There was no significant difference between the groups with respect to the Constant score. Conclusion: Accessory to suprascapular nerve transfer was not an efficient method for recovering active ROM or strength in the shoulder. However, it effectively improved pain control and shoulder stability. Level of evidence II, Retrospective Study.
\end{abstract}

Keywords: Brachial plexus. Nerve transfer. Accessory nerve. Shoulder.

\section{RESUMO}

Objetivo: A transferência de nervos é uma alternativa na reconstrução das lesões traumáticas do plexo braquial. Neste estudo, relatamos os resultados da reconstrução do plexo braquial com a transferência do nervo acessório para o nervo supraescapular. Métodos: Trinta e três pacientes com lesões traumáticas do plexo braquial foram submetidos à reconstrução cirúrgica com transferência do nervo acessório para o nervo supraescapular. Os pacientes foram divididos em grupos em que a cirurgia foi realizada dentro de 6 meses a partir da lesão ou mais de 6 meses depois da lesão. Os resultados foram avaliados com o escore Constant. Resultados: Não houve diferença significante entre os grupos com relação ao escore Constant. Conclusão: A transferência do nervo acessório para o nervo supraescapular não foi um método eficiente para recuperar a ADM ativa ou a força no ombro. No entanto, foi eficiente para melhorar o controle da dor e a estabilização do ombro. Nível de evidência II, Estudo Retrospectivo.

Descritores: Plexo braquial. Transferência de nervo. Nervo acessório. Ombro.

Citation: Abdouni YA, Checoli GF, Salles Filho HC, Costa AC, Chakkour I, PMMB Fucs. Assessment of the results of accessory to suprascapular nerve transfer. Acta Ortop Bras. [online]. 2018;26(5):332-4. Available from URL: http://www.scielo.br/aob.

\section{INTRODUCTION}

Traumatic brachial plexus injuries represent a severe, debilitating condition. They are frequent among young adults, and $75 \%$ of the time, there is a compromise of the supraclavicular portion of the plexus. ${ }^{1}$ Shoulder motor innervation is provided by the superior trunk of the brachial plexus through the axillar and suprascapular nerves. Patients presenting with a proximal injury of the brachial plexus are usually unable to flex, abduct or externally rotate their shoulder. ${ }^{2}$ When microsurgical reconstruction is feasible, nerve grafts or transfers are employed to repair nerve damage..$^{3,4}$ The cranial accessory nerve was the first to be employed as a donor for brachial plexus injuries and was frequently transferred to the suprascapular nerve to stabilize the shoulder and improve its function through reinnervation of the supraspinal, infraspinal and teres minor muscles. ${ }^{5}$
Currently, unreliable results from previous reports have made the efficacy of the accessory to supraspinal nerve transfer inconclusive. ${ }^{6-8}$ A functional score, therefore, is necessary to objectively assess the results of one of the most commonly performed surgical reconstructions of the brachial plexus.

In 1987, Constant and Murley ${ }^{9}$ presented a functional, easily applicable score for the shoulder that proved to be reproducible by many observers and was sensitive enough to detect even minor functional deficits. The Constant score is a scale from 0 to 100 points that evaluates objective and subjective criteria and has become a mainstream assessment tool for shoulder function among European orthopedic surgeons.

In this study, we assessed the results obtained from accessory to suprascapular nerve transfer, including shoulder joint stability, active

All authors declare no potential conflict of interest related to this article.

Work conducted at Irmandade da Santa Casa de Misericórdia de São Paulo, Hand Surgery and Microsurgery Group, Departamento of Orthopaedics and Traumatology, São Paulo, SP, Brazil. Correspondence: Rua Dr. Cesário Motta Júnior, 112, São Paulo, SP, Brazil. 01221-020. dr.yussefali@gmail.com 
ROM recovery and overall shoulder strength, and we compared the results from surgical procedures performed up to 6 months after the traumatic event to the results of surgery performed more than 6 months after the trauma.

\section{MATERIALS AND METHODS}

This study was performed by the Hand Surgery Department in the Orthopaedics and Trauma Center. In this retrospective cohort, 33 patients were selected who all suffered a traumatic brachial plexus injury and underwent accessory to suprascapular nerve transfer in the period between the years 2010 to 2015 .

The average patient age was 36.7 years. The average time between the traumatic event and surgery ranged from three to 17 months, with an average of 7.6 months. In this study, the patients were distributed into two groups. Group one (15 patients) comprised patients who underwent surgery within 6 months after the traumatic event. Group two (18 patients) comprised patients who underwent surgery more than 6 months after the traumatic event.

The brachial plexus injury presented as an isolated C5-C6 root injury in 78\% of the patients. An Erb-Plus pattern (C5-C6-C7) was encountered in $12 \%$ of the patients. Pan-plexus injuries were observed in $6 \%$ of the patients, and only one patient sustained a complete $\mathrm{C} 5-\mathrm{C} 6$ root injury and a partial C7-C8-T1 root injury. All surgical procedures included accessory nerve transfer to the suprascapular nerve, except for one patient who had an accessory nerve that could not be located. This patient was excluded from our study.

All remaining patients were evaluated using the Constant score, which included both subjective and objective criteria. First, the following were evaluated: pain, activities of daily living and global hand positioning. Second, shoulder ROM and shoulder strength were assessed. A standard goniometer was used during the measurements, whereas strength was evaluated subjectively. The differences in points between the injured member and the contralateral shoulder were classified as excellent (less than 11 points difference), good (11 to 20 points difference), regular (21 to 30 points difference) and poor (more than 30 points difference). All of the patients were evaluated by the senior surgeon of the group. A descriptive statistical analysis was performed for the population under investigation. Following that analysis, both time from trauma to surgery and the Constant score were evaluated.

A Spearman rank correlation coefficient was obtained for all compiled data, and two proportions tests were performed using Minitab 16 software. Only P-values lower than 0.05 were considered statistically significant.

The study was approved by the local institutional ethics review board (approval number: 1.089.394) and all patients signed an informed consent form before inclusion in the study.

\section{RESULTS}

The statistical analysis showed no significant difference between the groups with respect to the total Constant score (Table 1). We also did not encounter statistically significant differences between the groups when evaluating the individual tests for the scores (Tables 2 - 6).

Table 1. Correlation between Constant scores according to time from injury to surgery.

\begin{tabular}{c|c|c}
\hline Time from injury to surgery (months) & Correlation $(\mathbf{r})$ & P-value \\
\hline$\leq 6$ & $-22.7 \%$ & 0.456 \\
\hline$>6$ & $-44.9 \%$ & 0.081 \\
\hline
\end{tabular}

Table 2. Pain intensity after the procedure.

\begin{tabular}{|c|c|c|c|c|c|}
\hline \multirow{2}{*}{$\begin{array}{l}\text { Pain after the } \\
\text { procedure }\end{array}$} & \multicolumn{2}{|c|}{$\leq 6 \mathrm{~m}$} & \multicolumn{2}{|c|}{$>6 \mathrm{~m}$} & \multirow{2}{*}{ P-value } \\
\hline & $\mathrm{N}$ & $\%$ & $\mathrm{~N}$ & $\%$ & \\
\hline Severe & 2 & $15.4 \%$ & 3 & $18.8 \%$ & 0.811 \\
\hline Moderate & 3 & $23.1 \%$ & 2 & $12.5 \%$ & 0.453 \\
\hline Low & 2 & $15.4 \%$ & 2 & $12.5 \%$ & 0.823 \\
\hline None & 6 & $46.2 \%$ & 9 & $56.3 \%$ & 0.588 \\
\hline
\end{tabular}

\begin{tabular}{c|c|c|c|c|c} 
Table 3. Most functional shoulder position after the procedure. \\
\hline $\begin{array}{c}\text { Shoulder Functional } \\
\text { Position }\end{array}$ & \multicolumn{3}{|c|}{$\leq \mathbf{6 ~} \mathbf{~}$} & \multicolumn{3}{|c}{$>\mathbf{6 ~ \mathbf { ~ }}$} & \multirow{2}{*}{ P-value } \\
\cline { 2 - 5 } & $\mathbf{N}$ & $\%$ & $\mathbf{N}$ & $\%$ & \\
\hline Waist & 7 & $53.8 \%$ & 7 & $43.8 \%$ & 0.588 \\
\hline Xyphoid & 4 & $30.8 \%$ & 8 & $50.0 \%$ & 0.296 \\
\hline Neck & 1 & $7.7 \%$ & 1 & $6.3 \%$ & 0.879 \\
\hline Head & 1 & $7.7 \%$ & 0 & $0.0 \%$ & 0.259 \\
\hline
\end{tabular}

\begin{tabular}{|c|c|c|c|c|c|}
\hline \multirow{2}{*}{ Shoulder Flexion } & \multicolumn{2}{|c|}{$\leq 6 \mathrm{~m}$} & \multicolumn{2}{|c|}{$>6 \mathrm{~m}$} & \multirow{2}{*}{ P-value } \\
\hline & $\mathrm{N}$ & $\%$ & $\mathrm{~N}$ & $\%$ & \\
\hline $31-60^{\circ}$ & 6 & $46.2 \%$ & 12 & $75.0 \%$ & 0.111 \\
\hline $61-90^{\circ}$ & 4 & $30.8 \%$ & 2 & $12.5 \%$ & 0.227 \\
\hline $91-120^{\circ}$ & 2 & $15.4 \%$ & 2 & $12.5 \%$ & 0.823 \\
\hline $121-150^{\circ}$ & 1 & $7.7 \%$ & 0 & $0.0 \%$ & 0.259 \\
\hline
\end{tabular}

Table 5. Maximum active shoulder elevation obtained after the procedure.

\begin{tabular}{|c|c|c|c|c|c|}
\hline \multirow{2}{*}{ Shoulder Elevation } & \multicolumn{2}{|c|}{$\leq 6 \mathrm{~m}$} & \multicolumn{2}{|c|}{$>6 \mathrm{~m}$} & \multirow{2}{*}{ P-value } \\
\hline & $\mathbf{N}$ & $\%$ & $\mathbf{N}$ & $\%$ & \\
\hline $31-60^{\circ}$ & 8 & $61.5 \%$ & 11 & $68.8 \%$ & 0.684 \\
\hline $61-90^{\circ}$ & 4 & $30.8 \%$ & 3 & $18.8 \%$ & 0.452 \\
\hline $91-120^{\circ}$ & 1 & $7.7 \%$ & 2 & $12.5 \%$ & 0.672 \\
\hline
\end{tabular}

Table 6. Maximum active shoulder external rotation obtained after the procedure.

\begin{tabular}{c|c|c|c|c|c} 
Shoulder External Rotation & \multicolumn{2}{|c|}{$\leq 6 \mathrm{~m}$} & \multicolumn{2}{|c|}{$>6 \mathrm{~m}$} & \multirow{2}{*}{ P-value } \\
\cline { 2 - 5 } & $\mathbf{N}$ & $\%$ & $\mathbf{N}$ & $\%$ & \\
\hline $\begin{array}{c}\text { Hand behind head, } \\
\text { elbow forward }\end{array}$ & 10 & $76.9 \%$ & 12 & $75.0 \%$ & \multirow{2}{*}{0.904} \\
\hline $\begin{array}{c}\text { Hand behind head, } \\
\text { elbow backwards }\end{array}$ & 3 & $23.1 \%$ & 4 & $25.0 \%$ & \\
\hline
\end{tabular}

\section{DISCUSSION}

The results following accessory nerve to suprascapular nerve transfer vary between studies. In a study including 21 patients, Malessy ${ }^{7}$ observed supraspinal and infraspinal muscle reinnervation in 85 and $75 \%$ of patients, respectively, through electromyographic examination. However, active shoulder abduction and external rotation with muscle strength equal to or greater than 3 were present in only 24 and $14 \%$ of patients, respectively. Conversely, Terzis et al ${ }^{8}$ observed good to excellent results regarding shoulder abduction and external rotation in 79 and $55 \%$ of patients, respectively. The best results were encountered when surgery was performed within 6 months after the injury and no nerve grafting was used. Our results were closer to the results of Malessy ${ }^{7}$ than to those of Terzis: we did observe supraspinal muscle reinnervation indirectly through shoulder stability improvements, but only three patients had a shoulder abduction ROM greater than 90 degrees. There was no statistically 
significant difference between the patients who were operated on within six months of their injury and those who were operated on more than six months after injury in our study.

In a study of 30 patients, Bertelli and Ghizoni ${ }^{6}$ observed that shoulder abduction active ROM recovery occurred in patients subjected to accessory nerve to suprascapular nerve transfer, although the best results were achieved with partial injuries (45 vs 105 degrees). Regarding external rotation active ROM, no improvement was observed for the total injuries, whereas partial injuries had an average of 105 degrees of active ROM. In that study, however, partial injuries were treated with an additional motor branch transfer from the triceps to the axillary nerve. Our study did not evaluate partial and total injuries because of the limited number of patients with total brachial plexus injuries.

Souza et $\mathrm{al}^{10}$ evaluated 20 patients who were subjected to accessory nerve to suprascapular nerve neurotization through both anterior and posterior approaches, and they concluded that the best results were obtained through the latter, possibly due to a shorter reinnervation distance and because the suture was performed distally to the suprascapular notch, where there might be a secondary injury. In our study, all procedures were performed through the anterior approach, and only the accessory nerve transfer was included. A double neurotization, including a radial nerve branch to the axillary nerve transfer, would bias the accessory nerve transfer evaluation. We found no reports that included a functional score evaluation in addition to active ROM measurements, which sets our study apart from the others.
In our study, although abduction and external rotation active ROM did not change when both groups were compared, shoulder stability and pain showed statistically significant improvements when surgery was performed within 6 months after the injury. We found that pain relief was linked to shoulder inferior subluxation correction after supraspinal muscle reinnervation.

Shoulder anterior articular contracture may play a role in residual external rotation and abduction ROM limitations. However, there was no statistically significant difference in ROM between both groups in our study. An early rehabilitation program started soon after the injury itself may help achieve better post-operative results.

In our context of a tertiary public health center, we found that most patients came to us later. Therefore, many patients are not operated on in a timely manner, which may have diminished our post-operative results. Additionally, because this was a retrospective study, time between injury and surgical treatment could not be defined beforehand.

\section{CONCLUSION}

Accessory to suprascapular nerve transfer was not efficient for recovering active ROM or strength in the shoulder. It did, however, help with stabilizing the shoulder and improving pain and a statistically significant difference was observed between the results of surgeries performed within 6 months of the injury and those performed more than 6 months after the injury for these two variables.

AUTHORS' CONTRIBUTIONS: Each author contributed individually and significantly to the development of this manuscript. YAA (0000-0003-0752-5128) performed all surgeries and along with HCSF (0000-0003-0327-7905)* and GFC (0000 -0002-9707-5353)* performed follow-up of the patients and gathered clinical data. The study was designed by YAA and PMMBF (0000-0001-7081-987X)*. HCSF, GFC and ACC (0000-0002-5039-8884)* carried out the bibliographic research and evaluated the data of the statistical analysis. YAA and ACC were the main contributors in the writing of the manuscript and the review was done by PMMBF and IC (0000-0003-3870-0523)* * ORCID (Open Researcher and Contributor ID).

\section{REFERENCES}

1. Alnot JY, Rostoucher P, Oberlin C, Touam C. [C5-C6 and C5-C6-C7 traumatic paralysis of the brachial plexus of the adult caused by supraclavicular lesions]. Rev Chir Orthop Reparatrice Appar Mot. 1998;84(2):113-23.

2. Alnot JY. [Paralytic shoulder secondary to post-traumatic peripheral nerve lesions in the adult]. Acta Orthop Belg. 1999;65(1):10-22.

3. Chuang DC. Neurotization procedures for brachial plexus injuries. Hand Clin. 1995;11(4):633-45

4. Terzis JK, Kostas I. Suprascapular nerve reconstruction in 118 cases of adult posttraumatic brachial plexus. Plast Reconstr Surg. 2006; 117(2):613-29.

5. Tuttle HK. Exposure of the brachial plexus with nerve-transplantation. JAMA. 1913;61(1):15-7

6. Bertelli JA, Ghizoni MF. Transfer of the accessory nerve to the suprascapular nerve in brachial plexus reconstruction. J Hand Surg Am. 2007;32(7):989-98.

7. Malessy MJ, de Ruiter GC, de Boer KS, Thomeer RT. Evaluation of suprascapular nerve neurotization after nerve graft or transfer in the treatment of brachial plexus traction lesions. J Neurosurg. 2004;101(3):377-89.

8. Terzis JK, Kostas I, Soucacos PN. Restoration of shoulder function with nerve transfers in traumatic brachial plexus palsy patients. Microsurgery. 2006;26(4):316-24.

9. Constant $\mathrm{CR}$, Murley $\mathrm{AH}$. A clinical method of functional assessment of the shoulder. Clin Orthop Relat Res. 1987;(214):160-4.

10. Souza FH, Bernardino SN, Filho HC, Gobbato PL, Martins RS, Martins HA, et al. Comparison between the anterior and posterior approach for transfer of the spinal accessory nerve to the suprascapular nerve in late traumatic brachial plexus injuries. Acta Neurochir (Wien). 2014;156(12):2345-9. 